\title{
The Systematics of Intellectual Capital (a discussion of current concepts)
}

\author{
Iryna Rykovska*
}

\begin{abstract}
The aim of this paper is to formulate the economic substance of Intellectual capital. The comparative analysis of definitions and classifications of Intellectual capital was made on the basis of literary sources, and its comprehensive characterization was presented.

In view of the economic nature of each type of capital, as well as its specific features related to a personal factor and knowledge aspects, the new definition in two options was proposed, i.e. the narrow and the broad definition, the basic three-element structure was suggested. The objectives were also presented, for the achievement of which it is necessary to expand this classification.

The suggested system should form the basis for the development of methods for assessing start-up projects for the Innovation Management and Technology Transfer Centre in Warsaw Polytechnic University.
\end{abstract}

Keywords: capital, intellectual capital, human capital, structural capital, client capital, definition, classification

\section{Introduction}

The growing pace of scientific and technological progress affects the volatility of the structure and nature of business resources, where the aspect of innovation and intellectual resources is particularly important. Knowledge is usually the most valuable kind of resource and at the same time extremely specific, if only because it is the only resource whose size (value in the broad sense) increases during use.

One of the foundations of economics is the observation that changes in the means of production lead to changes in production relations. Modern economic development in companies is characterized by the integration of various forms of capital (physical, financial, labour and intellectual), which would not be possible without changes in property relations.

The reflection of these processes is the emergence in the economic sciences of a number of new concepts that can be divided into two basic categories:

- intellectual capital, which includes the concepts of: intellectual property, intellectual property objects, results of intellectual activity,

- intangible assets (resources).

\footnotetext{
* Master Iryna Rykovska, Faculty of Management of Warsaw University of Technology, e-mail: irinavitalia@gmail. com.
} 
These terms are defined in different ways and the search continues for an unambiguous interpretation, while the concept of intellectual capital is used more by managers, specialists in the field of intellectual property, and lawyers, and the concept of intangible assets by financiers. This is so because there are in fact different notional scopes. Intellectual property has a narrower meaning, referring as it does to property rights, designed to ensure that they in themselves bring income. In contrast, intangible assets are understood more broadly to include any intangibles in a company that can generate income. It should be noted that these categories have their own specific inner structure (certain objects) that must be taken into consideration, thus avoiding errors in their identification, documentation, assessment and management (Rykovska 2005: 352). In this case, it is worth noting that this applies not only to the academic disciplines, but also the management of a particular subject.

The term intellectual capital was used for the first time in 1958 by two financial analysts, commenting on the stock quotes of several small businesses based on knowledge (Mikuła, Pirtusza-Ortyl, Potocki 2007: 73). Despite the passage of 57 years a uniform approach to terminology or the spirit of this concept has still not been formed. As a result, in certain situations it is necessary to explain the interpretation of terms, and what's more - because of the absence of a common model the process of managing and evaluating intellectual capital is hindered.

It has been assumed that this issue requires detailed research, including an analysis of its economic nature and determination of its properties. The author is preparing a paper in this area, and this article is a report of the study.

\section{Discussion of definitions}

An overview of the common concepts of intellectual capital is shown in Table 1.

\section{Table 1}

Overview of the concepts of intellectual capital

\begin{tabular}{|c|c|c|}
\hline No. & Author and source & Definition and structure of intellectual capital \\
\hline 1 & 2 & 3 \\
\hline 1. & $\begin{array}{l}\text { Bukowitz, Williams } \\
\text { (2000: 223) }\end{array}$ & $\begin{array}{l}\text { Intellectual capital, unlike other resources, is a form of intangible asset, which, thanks to flows } \\
\text { of knowledge, creates greater wealth. }\end{array}$ \\
\hline 2. & $\begin{array}{l}\text { Booth R. } \\
\text { (Mikuła, Pirtusza-Ortyl, } \\
\text { Potocki 2007: 7) }\end{array}$ & $\begin{array}{l}\text { Intellectual capital is the ability to transform new ideas into products or services. } \\
\text { people (competences, attitudes) } \\
\text { market (standing, relationship with customers, distribution channels) } \\
\text { knowledge (confidential, open) } \\
\text { infrastructure (processes, databases) } \\
\text { intellectual property (patents, trademarks). }\end{array}$ \\
\hline 3. & $\begin{array}{l}\text { Bratnicki } \\
(2000: 100-101)\end{array}$ & $\begin{array}{l}\text { Intellectual capital is the sum of knowledge possessed by the people creating the community } \\
\text { of a business and the practical transformation of this knowledge into components of value for } \\
\text { the enterprise. } \\
\text { - Social capital (structural capital, dimension of relations between people, cognitive capital). } \\
\text { - Human capital (competency, intellectual skill, motivation). } \\
\text { - Organizational capital (internal structure, external structure, development capital). }\end{array}$ \\
\hline
\end{tabular}




\begin{tabular}{lll}
\hline 1 & 2 & 3 \\
\hline 4. & Bratnicki, Strużyna & $\begin{array}{l}\text { Intellectual capital is divided into two main parts: the first represents the invisible resources } \\
\text { and processes and creates organizational capital and social capital, while the second reflects the } \\
\text { knowledge of people and creates human capital. This division corresponds to the unconscious } \\
\text { and the conscious (thinking) parts of intellectual capital. }\end{array}$
\end{tabular}

5 Brooking (1996: 12-17) Intellectual capital is the result of the implementation and synergistic cooperation of several sub-processes, i.e. the formulation of a market strategy, knowledge management, selection of appropriate instruments for shaping the organization, management of intellectual property).

$6 \quad$ Brooking (1997: 364) Intellectual capital includes 4 areas:

- market strength - sales markets, customer loyalty,

- intellectual properties, such as: patents, brand value,

- internal aspects such as: corporate culture, management, processes, systems,

- properties that come from employees of the company, such as: competences, work-related know-how, knowledge, abilities, relationships.

7. Edvinsson, Malone (2001: 39-40); Intellectual capital is a non-financial asset that reflects the hidden gap between market and accounting value.

Jabłoński (2009: 57)

Intellectual capital is knowledge, experience, organizational technology, customer relationships, and professional skills that provide a competitive advantage in the market.

8. Edvinsson, Sullivan (1996: 363)

9. Eustace C., Goldfinger C., Storving C. (Mikuła, Pirtusza-Ortyl, Potocki 2007: 77) Intellectual capital is knowledge that can be converted into value.

Intellectual capital is the sum of two components:

- intangible goods (licenses, quotas, franchises, copyrights, patents, trademarks, brands, projects, know-how, trade secrets), i.e. assets, whose rights are indisputably owned by the organization, i.e. those which may be the subject of buying, selling, or stock exchange transactions, and which also have legal protection; this form of intellectual capital is thus to some extent measurable,

- intangible competences (innovative competencies, structural competences, market competences, human resources) which relate to specific factors determining the competitive advantage of the company and differentiating the organization from its market rivals; this component of intellectual capital relates to soft management spheres, so it is difficult to identify and evaluate.

10. Fitz-Enz

(2001: 23-24, 98)

11. Adamaska (2004: 192) "Hidden" company assets that are not fully captured in the accounts reporting, but are in some

Intellectual capital includes two categories: the intellectual property of the company and the complicated tangle of processes and culture, combined with a network of different kinds of relationships and human capital.

Intellectual capital is assets that remain in the company even if employees leave it. way formalized and used to create assets with a higher value.

Intellectual capital is a heterogeneous category, containing the interacting elements:

- capital directly related to employees, their skills, experience, qualifications, education (human capital, also employee capital),

- capital related to the company's organizational infrastructure (structural capital, also called organizational capital),

- capital linked with the company's external relations with its environment (client capital, also called market capital).

12. Wacław (2010: 129) Intellectual capital - knowledge and skills of company employees. Today, we can assume that, as techniques and technologies for producing capital progress, it will occupy an increasingly important position in the organization, and the improvement of methods of cooperation will precisely become the main method of using this capital, ultimately decisive for the competitiveness of the company.

13. Marcinkowska (2000: 93)

14. Perechuda (1999: 65) Intellectual capital is the knowledge of employees and management, which is a resource of strategic importance affecting the competitive position and market potential of the company. It is a resource that is very difficult both to evaluate and to protect from loss.

Intellectual capital is management skills, which when consumed in company processes is able to generate added value.

It includes the following components:

- human resources which generate added value,

- intellectual assets which are a source of innovation and represent the intangible assets of the company. 


\begin{tabular}{|c|c|c|}
\hline 1 & 2 & 3 \\
\hline 15. & $\begin{array}{l}\text { Roos J., G. Roos, Drag- } \\
\text { onetti NC, Edvisson L. } \\
\text { (Mikuła, Pirtusza-Ortyl, } \\
\text { Potocki 2007: 77); } \\
\text { Jabłoński (2009: } 57 \text { ) }\end{array}$ & $\begin{array}{l}\text { Intellectual capital formed by two of its components: } \\
\text { - human capital (the thinking part of intellectual capital): the competencies, attitudes and intel- } \\
\text { lectual abilities of employees, } \\
\text { - structural capital (the unconscious part of intellectual capital): dependent on business rela- } \\
\text { tionships with external actors, and its value is derived from the organization itself, its internal } \\
\text { structure, processes and culture, and strategy for reconstruction and development. }\end{array}$ \\
\hline 16. & $\begin{array}{l}\text { Stewart (1997: 1-3); } \\
\text { Mikuła, Pirtusza-Ortyl, } \\
\text { Potocki (2007: 76); } \\
\text { Jabłoński (2009: 57) }\end{array}$ & $\begin{array}{l}\text { Intellectual capital is the sum of everything that everybody in a company knows, and that deter- } \\
\text { mines the competitive advantage of the company. It is knowledge which allows the constituent } \\
\text { elements at the organization's disposal to be given a specific value, which enables it to convert } \\
\text { its resources into a specific financial value: } \\
\text { - Human capital } \\
\text { - Structural capital } \\
\text { - Client capital. }\end{array}$ \\
\hline 17. & Skrzypek (1999: 5) & $\begin{array}{l}\text { The basis of intellectual capital is the knowledge useful for companies, that is, that which can } \\
\text { be transformed for their good. It is knowledge that is productive. Intellectual capital includes } \\
\text { knowledge, communication, intuition, and the feelings and desires of employees. }\end{array}$ \\
\hline 18. & $\begin{array}{l}\text { Mikuła, Pirtusza-Ortyl, } \\
\text { Potocki (2007: 79-80) }\end{array}$ & $\begin{array}{l}\text { Intellectual capital can be defined as the sum of the knowledge possessed by the people forming } \\
\text { organizations, and enabling transformation of its resources into measurable financial value for } \\
\text { the company. This concept comprises all the interdependencies between its components and the } \\
\text { whole flow of knowledge between them, in the form of the processes of generating, acquiring, } \\
\text { transforming and pooling of knowledge as well as their effects, such as intellectual property. } \\
\text { Intellectual capital is therefore part of the total value of the company that represents the dif- } \\
\text { ference between the market and book value of the company and enables organizations to gain } \\
\text { a competitive advantage in the market. } \\
\text { In intellectual capital so defined, there are two components that build it - social capital and } \\
\text { organizational capital. }\end{array}$ \\
\hline 19. & Wiig (1997: 400) & $\begin{array}{l}\text { Intellectual capital consists of assets resulting from intellectual activity, ranging from the } \\
\text { acquisition of new knowledge (learning), through ingenuity, to creating valuable relationships } \\
\text { with others. }\end{array}$ \\
\hline
\end{tabular}

Source: own report.

Table 1 shows that in the literature there are many dissimilar definitions of intellectual capital and similarly diverse classifications of its components. There is therefore a need for a uniform and comprehensive explanation of what intellectual capital is and hence it is necessary to examine the properties of the capital itself, and on this basis to propose its characteristics, definitions and classifications.

The concept of intellectual capital has been established relatively recently and is not stably formed, hence at the beginning of the analysis it should be looked at from a much more permanent perspective, i.e. the basic features of the company's capital and its classification as established in the economic sciences. The nature of capital in all its forms has for centuries been the focus of attention of economic thought. Along with socioeconomic development, according to the level of development of the productive forces and relations of production, ideas have been formulated on what capital is. A definition close to the contemporary understanding of capital was already formulated in the 17th century with the advent of capitalist economic relations. The concept of capital (lat. capitalis - basic, the main part of property) has become the foundation of the scientific concept of these relationships. The precursor of economic sciences (Smith 1954) used the term in the sense of "accumulated resources", "accumulated property" and "finance", which are used for production, job creation, and receiving income. In the key economic 19th-century Marxist theory of political economy, 
capital is treated as a value that with the use of hired labour exploitation brings added value and is self-accumulating. In those circumstances - pre-industrial and early industrial economy - capital was identified exclusively with material production. The subsequent evolution of civilization has led to the modern economic reality and the new economy, in which the distinguishing features are two complementary spheres of production: material (created tangible values) and immaterial (creates spiritual, moral, spiritual culture, art, science, etc. values), and economic functioning also takes a virtual form. As a result of these changes new and more complex forms of capital appeared with a vast potential for economic activity. In particular, intellectual capital evolved, rapidly even becoming the leader in the innovative economy. Certainly, it determines the further development of each company in the new conditions so formed and still evolving. It sets the pace of development and the nature of the renewal of production technology and, consequently, is a source of potential competitive advantage in the market. The strength of this new type of capital lies in the variety of its forms, its constant development and in - in a sense - its self-contained and efficient recreation. The establishment of an objective picture of intellectual capital has been begun by examining the properties of capital as a general category (Table 2).

\section{Table 2}

Overview of definitions of capital

\begin{tabular}{|c|c|c|}
\hline No. & Author and source & Definition \\
\hline 1 & 2 & 3 \\
\hline 1. & Smith (1954: 324) & Capital is that portion of resources that brings their owner the expected income. \\
\hline 2. & $\begin{array}{l}\text { Marx }(1951: \\
155-156,160)\end{array}$ & $\begin{array}{l}\text { Money as money and money as capital initially only differ in different forms of circulation (Money- } \\
\text { Goods-Money). } \\
\text { The money that undergoes this circulation is transformed into capital, becomes capital and already in } \\
\text { its destiny is potentially capital. } \\
\text { The originally lined value is not only involved in circulation, but changes in its course in the size } \\
\text { of its value, increasing by a surplus value (M'), i.e. it multiplies. And this movement (M-G-M') } \\
\text { transforms it into capital. }\end{array}$ \\
\hline 3. & $\begin{array}{l}\text { Wacław } \\
(2007: 155)\end{array}$ & $\begin{array}{l}\text { Outside capital - all a company's liabilities to creditors, i.e. loans and outside contributions which } \\
\text { are repayable sources of financing assets. These obligations may be long-term (e.g. mortgage obliga- } \\
\text { tions, equity or long-term bond loans and investment loans) or short-term (e.g. debts to suppliers, } \\
\text { insurance companies, tax authorities, employees, or short-term loans and bank loans). The company } \\
\text { may temporarily use outside funds due to different deadlines in maturities. }\end{array}$ \\
\hline 4. & $\begin{array}{l}\text { Czekaj, Dresler } \\
(1995: 558)\end{array}$ & $\begin{array}{l}\text { All elements that appear on the liabilities side of the company's balance sheet, and constitute } \\
\text { a source of funding for assets accumulated in the enterprise. }\end{array}$ \\
\hline 5. & $\begin{array}{l}\text { Dereń, Polański } \\
\text { (2012: 313) }\end{array}$ & $\begin{array}{l}\text { Capital: } \\
\text { 1. Fixed assets and financial assets of private individuals, businesses, institutions, etc., } \\
\text { with monetary value. } \\
\text { 2. A large sum of money, accumulated savings. } \\
\text { 3. Those possessing a large sum of money. }\end{array}$ \\
\hline 6. & Jajuga (2007: 12) & $\begin{array}{l}\text { Capital is an asset that can be used to provide future benefits, including the manufacture of other } \\
\text { assets. }\end{array}$ \\
\hline 7. & Fisher (1906: 52) & $\begin{array}{l}\text { The capital is any resource - everything that has a value and serves manufacturing and services, } \\
\text { which is important for the growth and development of the economy. }\end{array}$ \\
\hline 8. & $\begin{array}{l}\text { Szymczak } \\
(1978: 876)\end{array}$ & $\begin{array}{l}\text { Capital is: } 1 \text {. A value bringing to the capitalist added value in the form of profit, derived from the } \\
\text { work of hired workers; } 2 \text {. a significant amount of money, cash, funds, property. }\end{array}$ \\
\hline 9. & $\begin{array}{l}\text { Bernstein P.L. } \\
\text { (Gos 2013: 558) }\end{array}$ & $\begin{array}{l}\text { Capital is a specific economic category which represents accumulated goods (resources), designed to } \\
\text { implement and develop business, and is characterized by the value of having the ability to grow. }\end{array}$ \\
\hline
\end{tabular}




\begin{tabular}{|c|c|c|}
\hline 1 & 2 & 3 \\
\hline 10. & $\begin{array}{l}\text { Duliniec } \\
(2001: 13)\end{array}$ & Capital means funds (financial resources) entrusted to the company by its owners and creditors. \\
\hline 11. & $\begin{array}{l}\text { Janasz } \\
(2008: 69-70)\end{array}$ & $\begin{array}{l}\text { Capital is the sum of abstract values of the property involved in the company, which is expressed in } \\
\text { its balance sheet on the liabilities side. } \\
\text { In microeconomic terms, the general definition of capital is not used, but two concepts: } \\
\text { - real capital (in kind) } \\
\text { - financial capital (cash). }\end{array}$ \\
\hline 12. & $\begin{array}{l}\text { Marchewka } \\
(2000: 116)\end{array}$ & $\begin{array}{l}\text {...All that can be called capital are called goods called economic, material, and capital, from which } \\
\text { arise in the future other new goods }\end{array}$ \\
\hline 13. & $\begin{array}{l}\text { Matysiak } \\
(2008: 88-89)\end{array}$ & $\begin{array}{l}\text {... capital is a resource, which means that it generates defined advantages, and each definition as- } \\
\text { sumes them, even when it is stationary. The main feature of capital is movement, action, circulation, } \\
\text { and not existence. The resource of socially useful goods is - as you know - the property with the } \\
\text { appropriate adjective, not capital. Production assets can at most be considered only as potential } \\
\text { capital“. } \\
\text { "... Capital is a process, i.e. a sequence of certain kinetic events. In other words, these are repeated in } \\
\text { a certain definedorder events stretched in time, which result in defined effects. }\end{array}$ \\
\hline 14. & $\begin{array}{l}\text { Szczygielska } \\
(2009: 10)\end{array}$ & $\begin{array}{l}\text { A company's capital in the general sense can be defined in the simplest way as the accumulated good } \\
\text { that serves the development of production, or the cash resources necessary for production. Capital is } \\
\text { an economic category representing the value which characterizes the ability to grow. }\end{array}$ \\
\hline
\end{tabular}

Source: own report.

The abovementioned definitions show that capital is the most important economic category, which includes the following interacting components: labour, means of production, information resources, the relationships between production and property, and their interaction creates added value, which enables those components that wear out to be recreated. The combination of these elements in the whole system transforms the nature of each, whereby they are organic parts of capital. The numerousness of the concepts of capital can be explained by its structural complexity in static terms and the complexity of its operation in terms of dynamics. Thus, to this day there are efforts to create a semantically and logically comprehensive view of the characteristics of capital in the form of a comprehensive definition.

On the basis of the foregoing definition of capital and intellectual capital author definitions were formulated (Table 3), which is a synthesis of the analysed concepts and thus they meet the modern challenges of economic development and business management.

\section{Table 3}

General economic definition of capital and intellectual capital

\begin{tabular}{ll}
\hline In the broad sense & In the narrow sense \\
\hline $\begin{array}{l}\text { Capital represents all resources of a company that are involved in the } \\
\text { production process and are used to manufacture a large amount of } \\
\text { economic goods. }\end{array}$ & $\begin{array}{l}\text { Capital is the value of resources that produces added } \\
\text { value. }\end{array}$ \\
$\begin{array}{l}\text { Intellectual capital is the intellectual resources of all the companies } \\
\text { that are involved in the production process and are essential to the } \\
\text { production of a large amount of economic goods. }\end{array}$ & $\begin{array}{l}\text { Intellectual capital is the value of intellectual resources } \\
\text { that gives the surplus value in the production procedure. }\end{array}$ \\
\hline
\end{tabular}

Source: own report. 


\section{Systematic discussion}

The next step is to establish a universal system for so called intellectual capital. An essential component of a description of each complex economic category is to establish the taxonomy of its forms, manifestations, effects, etc. Classification is a division of objects or phenomena into classes, groups, divisions performed according to specific rules or criteria, the assessment of someone or something in a comparative scale (Dereń, Polanski 2012: 331). In other words, the classification is a system of dependent concepts (classes, objects, phenomena) in any discipline of science, based on the common features of objects naturally connected with each other. It gives the ability to identify each object individually and with contextual comparison with others is a source of precise knowledge about them. Every scientific classification is an important source of information, because it combines a set of methods for the study of phenomena or objects that form a conceptual whole by their division into classes, defined by a common feature. The classification process is not just a collection of individual objects, but also a study of their similarities, differences and relationships on the basis of their scientifically uniform principles and criteria. Finally and most important is that a division (decomposition) is made up of the entire set of information about the characteristics of the study objects in systemically ordered parts. This decomposition depends on the scientific justification of the characteristics under which it is implemented. Thus, the more classification criteria that can be identified, the greater the knowledge of the analysed phenomenon.

The classification of intellectual capital present in the literature was already partially presented in Table 1, and is included in detail in Table 4.

Table 4

Structure of intellectual capital

\begin{tabular}{lll}
\hline Author & $\begin{array}{l}\text { Elements of intellectual capital } \\
\text { structure }\end{array}$ & Components of elements \\
\hline 1 & 2 & 3 \\
\hline $\begin{array}{l}\text { Sveiby K.E. } \\
\text { (Mrożewski 2008: 32) }\end{array}$ & Human capital & $\begin{array}{l}\text { education, experience, skills (competencies), relationship } \\
\text { with the organization, vitality } \\
\text { patents, licences, know-how, marks, trademarks, govern- } \\
\text { ance, culture, processes, administrative systems, information } \\
\text { technology } \\
\text { image, trademark, relationships with suppliers, relationships } \\
\text { with customers }\end{array}$ \\
& External structural capital & \\
\hline $\begin{array}{l}\text { Kaplan R.S. } \\
\text { (Perechuda 2005: 135) }\end{array}$ & Customers & \\
& The internal structure of the company & \\
& Processes: learning and innovation & \\
\hline $\begin{array}{l}\text { Edvinsson, Malone } \\
\text { (2001: 41) }\end{array}$ & Financial & \\
\hline
\end{tabular}




\begin{tabular}{lll}
\hline 1 & 2 & 3 \\
\hline $\begin{array}{l}\text { Petrash G., } \\
\text { Edvinsson L., Onge H., }\end{array}$ & Human capital & $\begin{array}{l}\text { The ability of individuals and teams in meeting the require- } \\
\text { ments of clients, competencies, notions, etc. }\end{array}$ \\
$\begin{array}{l}\text { Armstrong C. } \\
\text { (Sokołowska 2005: 64) }\end{array}$ & $\begin{array}{l}\text { Client capital } \\
\text { Organizational capital }\end{array}$ & $\begin{array}{l}\text { the strength and value of customer relationships } \\
\text { the ability of companies in the creation of codified knowl- } \\
\end{array}$ \\
& $\begin{array}{l}\text { edge based on available databases and resources, business } \\
\text { processes, technology infrastructure, organizational culture } \\
\text { etc. }\end{array}$ \\
\hline
\end{tabular}

Brooking (1996:13) Marketable assets

Assets related to the human factor

Infrastructure Assets

Assets including intellectual value

\begin{tabular}{|c|c|c|}
\hline \multirow{3}{*}{$\begin{array}{l}\text { Stewart T.A. } \\
\text { (Mrożewski 2008: 32) }\end{array}$} & Human capital & skills, experience \\
\hline & Structural capital & patents, technology, processes \\
\hline & Capital related to customers & information about consumers and suppliers \\
\hline \multirow{3}{*}{$\begin{array}{l}\text { Bratnicki, Strużyna } \\
(2001: 15)\end{array}$} & Social capital & \\
\hline & Human capital & \\
\hline & Organizational capital & \\
\hline \multirow{2}{*}{$\begin{array}{l}\text { Ross G. Ross J. } \\
\text { (Sokołowska 2005: 15) }\end{array}$} & Human capital (,thinking assets“) & \\
\hline & $\begin{array}{l}\text { Structural capital (,non-thinking } \\
\text { assets“) }\end{array}$ & \\
\hline \multirow{3}{*}{$\begin{array}{l}\text { Baruch L. } \\
\text { (Jemielniak, Kozmin- } \\
\text { ski, 2012: 248) }\end{array}$} & Assets related to humans & \\
\hline & Organizational Assets & \\
\hline & Assets related to innovation & \\
\hline Fitz-Enz (2001: 24) & $\begin{array}{l}\text { Diagram of intellectual capital presents } \\
\text { it as: } \\
\text { - Human capital } \\
\text { - processes and culture } \\
\text { - intellectual property } \\
\text { - relationships }\end{array}$ & \\
\hline \multirow[t]{2}{*}{ Perechuda (1999: 65) } & Human resources & Human assets generate added value \\
\hline & Intellectual assets & $\begin{array}{l}\text { they are a source of innovation and represent the intangible } \\
\text { assets of an undertaking; they are divided into three groups: } \\
\text { - focusing on the commercialization of products, processes } \\
\text { and services; } \\
\text { - cultivating long-term relationships with clients: relation- } \\
\text { ships, contracts, history of management by the company; } \\
\text { - structural: plans, procedures, processes. }\end{array}$ \\
\hline \multirow{4}{*}{$\begin{array}{l}\text { Warschat J., } \\
\text { Wanger K., Hauss J. } \\
\text { (Mrożewski 2008: 3) }\end{array}$} & Human capital & competences, attitudes, leadership and development \\
\hline & Organizational capital & processes, infrastructure, culture, management \\
\hline & Market capital & $\begin{array}{l}\text { relationships with customers, relations with suppliers, market } \\
\text { expertise, other relationships }\end{array}$ \\
\hline & Innovation capital & improving processes, products and services, technologies \\
\hline
\end{tabular}




\begin{tabular}{lll}
\hline 1 & 2 & 3 \\
\hline Rowińska-Fronczek M. & Intellectual capital, individual & personal technical capital, creating new products, creating \\
(Mrożewski 2008: 32) & and implementing technological progress, create new \\
& quality products and production processes; \\
& - personal organizational capital directed inside: develop- \\
& ment of organizational processes, building structures, \\
& creating the culture of the organization; \\
& - personal organizational capital directed to markets: \\
& development of relations with the market, building lasting \\
& relationships with customers, building organizational \\
& strategy;
\end{tabular}

Intellectual capital, impersonal regulations, organizational structure, formulas, patents, licences, know-how, databases, copyrights, trademarks, trade names and other

\begin{tabular}{|c|c|c|}
\hline \multirow{3}{*}{$\begin{array}{l}\text { Skuza B. } \\
\text { (Mrożewski 2008: 33) }\end{array}$} & Human capital & competencies, relationships, values \\
\hline & Organizational capital & process capital, innovation, culture \\
\hline & Capital in the form of customers & $\begin{array}{l}\text { customer base, relationships with customers, customer } \\
\text { potential }\end{array}$ \\
\hline \multirow[t]{3}{*}{ Król (2006: 96-97) } & Human capital & $\begin{array}{l}\text { knowledge, skills, abilities, health, motivation, attitudes, } \\
\text { values }\end{array}$ \\
\hline & Organizational capital & $\begin{array}{l}\text { databases, customer records, trademarks, organizational } \\
\text { structures, patents, copyrights, IT systems }\end{array}$ \\
\hline & Capital in external relations & $\begin{array}{l}\text { contacts with customers, suppliers, competitors, the media } \\
\text { and the local community }\end{array}$ \\
\hline \multirow[t]{3}{*}{ Adamska (2004: 192) } & $\begin{array}{l}\text { Human capital } \\
\text { (employees) }\end{array}$ & competencies, relationships, values \\
\hline & Structural capital (organization) & process capital, innovation, organizational culture \\
\hline & $\begin{array}{l}\text { Client capital. } \\
\text { (market) }\end{array}$ & $\begin{array}{l}\text { customer base, relationships with customers, customer } \\
\text { potential }\end{array}$ \\
\hline \multirow[t]{3}{*}{$\begin{array}{l}\text { Bukowitz, Williams } \\
\text { (2000: 223) }\end{array}$} & Human capital & $\begin{array}{l}\text { abilities of individual persons and teams of employees to } \\
\text { meet customer needs, competencies, mental models }\end{array}$ \\
\hline & Client capital & strength of customer relationships \\
\hline & Organizational capital & $\begin{array}{l}\text { the ability of organizations located in codified knowledge } \\
\text { (databases, processes, telephone infrastructure, organiza- } \\
\text { tional culture, norms and value) }\end{array}$ \\
\hline \multirow{2}{*}{$\begin{array}{l}\text { Mikuła, Pirtusza-Ortyl, } \\
\text { Potocki (2007: 81) }\end{array}$} & Social capital & relationships within the organization, human capital \\
\hline & Organizational capital & $\begin{array}{l}\text { relational capital (customer potential, interaction with } \\
\text { stakeholders), innovative capital, organizational culture, } \\
\text { infrastructure (databases, intellectual property, organizational } \\
\text { structure, processes and their management, strategy and } \\
\text { systems of operation) }\end{array}$ \\
\hline \multirow[t]{3}{*}{ Kozyrev (2002: 5-7) } & Human capital & $\begin{array}{l}\text { labour force, good management, know-how that cannot be } \\
\text { separated from the individual, tacit knowledge }\end{array}$ \\
\hline & Structural capital & $\begin{array}{l}\text { intellectual property rights, information resources, instruc- } \\
\text { tions and methods of operation, system of organization, } \\
\text { systematic knowledge, know-how which can be separated } \\
\text { from the individual }\end{array}$ \\
\hline & $\begin{array}{l}\text { Market (client) } \\
\text { Capital }\end{array}$ & $\begin{array}{l}\text { trademarks and service marks, trade names, insiders, good- } \\
\text { will, contacts with customers. }\end{array}$ \\
\hline
\end{tabular}

Source: own report. 
An analysis of Table 4 shows that there is no single approach to the classification of intellectual capital. This fact demonstrates the necessity of the detailed research of different approaches in this regard, as a comparative summary of the information given in Table 5.

\section{Table 5}

Classifications of capital and intellectual capital

\begin{tabular}{|c|c|c|}
\hline Criterion & Capital & Intellectual capital \\
\hline 1 & 2 & 3 \\
\hline Source & $\begin{array}{l}\text { - internal } \\
- \text { external }\end{array}$ & --- \\
\hline Purposes of Use & $\begin{array}{l}\text { - production } \\
- \text { location } \\
- \text { speculative }\end{array}$ & --- \\
\hline Form & $\begin{array}{l}\text { - monetary } \\
\text { - material } \\
- \text { non-material }\end{array}$ & --- \\
\hline Form of financing & $\begin{array}{l}\text { - institutional } \\
\text { - financial }\end{array}$ & --- \\
\hline Form of circulation & $\begin{array}{l}- \text { monetary } \\
- \text { production } \\
- \text { commodity }\end{array}$ & --- \\
\hline Form of ownership & $\begin{array}{l}\text { - share } \\
\text { - state capital }\end{array}$ & --- \\
\hline Legal form of activity & $\begin{array}{l}\text { - joint-stock } \\
\text { - share } \\
\text { - individual }\end{array}$ & --- \\
\hline Nature of economic use & $\begin{array}{l}\text { - working } \\
\text { - non-working }\end{array}$ & --- \\
\hline Nature of use by owner & $\begin{array}{l}- \text { consumed } \\
- \text { collected }\end{array}$ & --- \\
\hline Source of acquisition & $\begin{array}{l}\text { - national capital } \\
\text { - foreign capital } \\
\text { - financial market } \\
\text { - capital market } \\
\text { - private sources }\end{array}$ & --- \\
\hline Compliance with legal norms & $\begin{array}{l}\text { - legal } \\
\text { - „grey area“ }\end{array}$ & --- \\
\hline $\begin{array}{l}\text { Generic according to (IAS } 1 \\
\text { 2008: 14) }\end{array}$ & $\begin{array}{l}\text { - share capital and remaining capitals are divided into different } \\
\text { categories such as: } \\
\text { - paid-in capital, } \\
\text { - surplus from the sale of shares above their nominal value, } \\
\text { - other reserves. }\end{array}$ & $\begin{aligned} \text { - } & \text { Human capital } \\
& \text { (employees); } \\
- & \text { Structural capital } \\
& \text { (organization) } \\
- & \text { Client (market) }\end{aligned}$ \\
\hline $\begin{array}{l}\text { Generic according to the Ac- } \\
\text { counting Act (2015: 118-119) }\end{array}$ & $\begin{array}{l}\text { 1. Basic capital (fund) basic } \\
\text { 2. Share (fund) capital, including: } \\
- \text { surplus sales value (issue value) over nominal value of shares } \\
\text { 3. Capital (fund) from updating the valuation, including: } \\
- \text { revaluation of fair value } \\
\text { 4. Other reserves (funds), including: } \\
- \text { created in accordance with the agreement (statute) of the } \\
\text { company in its own shares (stocks) } \\
\text { 5. Profit (loss) from previous years } \\
\text { 6. Profit (loss) net } \\
\text { 7. Write-offs of net profit during the financial year (negative value) }\end{array}$ & capital. \\
\hline
\end{tabular}




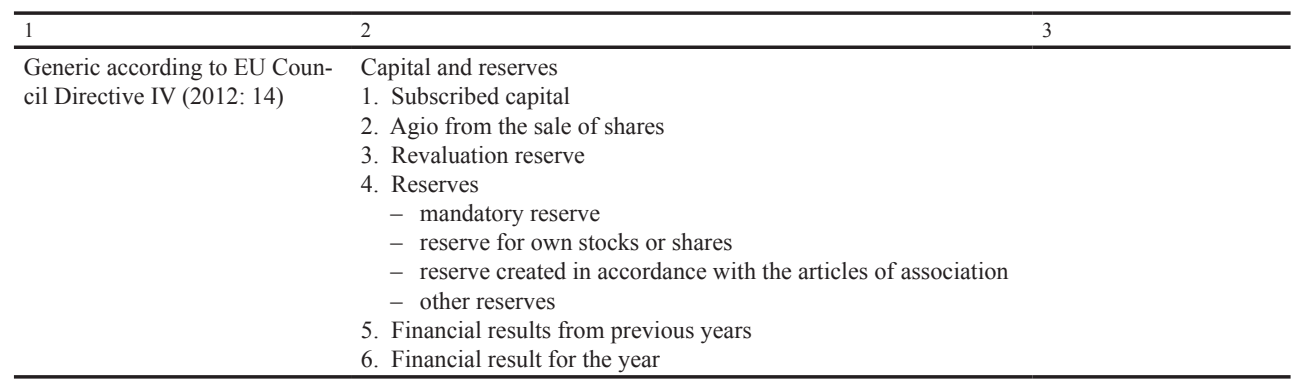

Source: own report based on: IAS 1, the Accounting Act; IV EU Council directive.

On the basis of the foregoing classification of capital and intellectual capital, the author's division was formulated. It was also recognized that the consistent division which complies with recent economic challenges is the division by human capital, structural (organizational) capital and client (market) capital (see Table 5).

\section{Conclusions}

The intellectual capital management process is complicated because this category includes many different objects. Today, the most famous out of the applied practical models for intellectual capital management are: Navigator of Skandia, the Konrad Report, Cost Platform and Intangible Assets Monitor (Skrzypek 2014: 105). Nevertheless, the best practices for intellectual capital management have not been established yet, which does not allow for the effective use of this type of capital and leads to the fact that its usage is risky for most small and medium-sized companies. That is why, among other things, they are not very active in the field of innovation and prefer more traditional activities. That is why most companies who successfully use this type of capital, are those companies that can afford to finance their own research in this area.

For the effective use of intellectual capital in small and medium-sized enterprises in Poland, it is necessary to have a scientific concept agreed in the research community. It is also necessary to create research centers, which will be developing it not only scientifically but also in practice; and thus there will be representatives of the economy sector who can consult with scientists, work out special management models appropriate to their individual circumstances and at the same time comply with the standards of theoretically grounded good practice.

Previous studies have revealed a number of problems connected with theoretical description and practical applications. The primary problem is that its economic part is poorly researched and this results in the lack of uniform terminology and interpretation, which inhibits both business processes and further research. The concept of intellectual capital is often replaced by notions of intellectual assets, intangible assets, cost of knowledge and intellectual property. Meanwhile, one can even intuitively feel the subtle differences in the meaning. 
That is why the article describes the problem of a definition of intellectual capital and classification. All these resulted in two basic conclusions:

1. On the basis of literature studies in order to define intellectual capital taking into account the economic nature of each type of the capital, as well as its specific features related to a personal factor and knowledge aspects, the new definition in two options was proposed, i.e. a narrow and broad definition, see Table 3.

2. Similarly, based on literature studies, in order to define the boundaries and structure of the intellectual capital as well as taking into account the fact that it is an integral part of the equity, in general, a basic three-element structure was suggested, see Table 5.

For effective intellectual capital management it is necessary to deepen this classification, which will be the next stage of research. This should lead to:

- a definition of principles for evaluation, control and management,

- a description of the life cycle and development of the life cycle model,

- a need for legal protection,

- research and improvement of the existing evaluation models.

\section{References}

IV dyrektywa Rady UE z 25 lipca 1978 r. w sprawie rocznych sprawozdań finansowych niektórych rodzajów spółek, wydana na podstawie artykułu 54 ust. 3 pkt g Traktatu (78/ 660/EEC) - tekst jednolity, według stanu na 10.04.12 r.

Bratnicki M. (2000), Podstawy wspótczesnego myślenia o zarządzaniu, „Triada”, Dąbrowa Górnicza.

Bratnicki M., Strużyna J. (2001), Przedsiębiorczość i kapitat intelektualny, Wydawnictwo Akademii Ekonomicznej w Katowicach, Katowice.

Brooking A. (1996), Intelectual Capital: Core Asset for the Third Millenium Enterprise, International Thomsom Business Press, London, pp. 12-17.

Brooking A. (1997), The Management of Intellectual Capital, "Long Range Planning” vol. 30. June, pp. 364-365.

Bukowitz W., Williams R.L. (2000), The Knowledge Management Fieldbook, Financial Time, Prentice Hall, London, p. 223.

Czekaj J., Dresler Z. (1995), Podstawy zarzadzania finansami firm, PWN, Warszawa.

Dereń E., Polański E. (2012), Wielki słownik języka polskiego, Krakowskie Wydawnictwo Naukowe. Kraków.

Duliniec A. (2001), Struktura i koszt kapitału w przedsiębiorstwie, Wydawnictwo Naukowe PWN, Warszawa.

Edvinsson L., Malone M.S. (2001), Kapitat intelektualny, Wydawnictwo Naukowe PWN, Warszawa.

Edvinsson L., Sullivan P. (1996), Developing a Model for Managing Intellectual Capital, "European Management Journal", vol.14, no. 4, pp. 356-364.

Fisher I. (1906), The Nature of Capital and Income, Macmillan, New York.

Fitz-Enz J. (2001), Rentowność inwestycji w kapitał ludzki, Dom Wydawniczy ABC, Kraków.

Gos W. (2013), Istota kapitałów, pieniądza oraz źródel finansowania, Zeszyty Naukowe Uniwersytetu Szczecińskiego nr 766, Finanse, Rynki Finansowe, Ubezpieczenia nr 62, pp. 557-569.

Jabłoński M. (2009), Zarządzanie wartościa przedsiębiorstw o orientacji jakościowej a kapitał intelektualny, Wydawnictwo Humanitas, Sosnowiec.

Jajuga K. (2007), Elementy nauki o finansach, Wydawnictwo Naukowe PWN, Warszawa.

Janasz K. (2008), Kapitał jako podstawa rozwoju przedsiębiorstwa, Studia i Prace Wydziału Nauk Ekonomicznych i Zarządzania Uniwersytetu Szczecińskiego nr 1.

Jemielniak D. (2012), Koźmiński A.K. (red.), Zarządzanie wiedza, WAiP, Warszawa.

Kapitat intelektualny $w$ gospodarce opartej na wiedzy (2009), red. A. Szczygielska, Wydawnictwo Uniwersytetu Ekonomicznego we Wrocławiu, Wrocław.

Kozyrev A.N. (2002), Evaluation of Intellektual Property and Intangible Assets, Working paper for discussion on high-level task force on valuation and capitalization of intellectual assets, Economik Commission for Europe, United Nations, 18 and 19 November. 
Leksykon zarządzania (2004), red. M. Adamaska, Difin, Warszawa.

Marchewka K. (2000), Główne nurty w teorii kapitału, „Ruch Prawniczy, Ekonomiczny i Socjologiczny” LXII zeszyt 3.

Marcinkowska M. (2000) Kształtowanie wartości firmy, Wydawnictwo Naukowe PWN, Warszawa.

Marx K. (1951), Kapitat, t. 1, KiW, Warszawa.

Matysiak A. (2008), Kapitat jako proces, Zeszyty Naukowe Polskiego Towarzystwa Ekonomicznego nr 6.

Międzynarodowy Standard Rachunkowości 1 - Prezentacja sprawozdań finansowych, Dziennik Urzędowy Unii Europejskiej, 29.11.2008.

Mrożewski M. (2008), Kapitat intelektualny wspótczesnego przedsiębiorstwa, Difin, Warszawa.

Perechuda K. (1999), Metody zarządzania przedsiębiorstwem, Wydawnictwo Akademii Ekonomicznej we Wrocławiu, Wrocław.

Podstawy zarządzania przedsiębiorstwami w gospodarce opartej na wiedzy (2007), ed. B. Mikuła, A. Pietuszka-Ortyl, A. Potocki, Difin, Warszawa.

Риковська I. (2005), Проблеми визнання нематеріальних активів, Збірник наукових праць III Міжнародної науково-практичної конференції «Стан і проблеми трансформації фінансів та економіки регіонів У перехідний період». Хмельницький: ХЕУ, ч. 2, pp. 352-355.

Skrzypek E. (1999), Wpływ zarządzania wiedza na jakość, "Problemy Jakości” nr 11, pp. 4-9.

Skrzypek E. (2014), Pomiar kapitału intelektualnego w przedsiębiorstwie - aspekty metodyczne, Wydawnictwo Naukowe UAM, Studia Metodologiczne nr 32.

Słownik języka polskiego (1978), ed. M. Szymczak, PWN, Warszawa.

Smith A. (1954), Badania nad natura i przyczynami bogactwa narodów, t. 1, ks. 2, r. 1, PWN, Warszawa.

Sokołowska A. (2005), Zarzadzanie kapitałem intelektualnym $w$ małym przedsiębiorstwie, Polskie Towarzystwo Ekonomiczne, Warszawa.

Stewart T. (1997), Intellectual Capital, The New Wealth of Organizations, Niholas Brealey, London, pp. 1-3.

Šmid W. (2010), Leksykon zarządzania zasobami ludzkimi, Publishing House Dr Lex, Kraków.

Šmid W. (2007), Leksykon przedsiębiorcy. Poltext, Warsaw.

Wiig K.M. (1997), Integrating Intellectual Capital with Knowledge Management, „Long Range Planning” vol. 30, no. 3, June, pp. 399-405.

Ustawa z 29 września 1994 r. o rachunkowości. Opracowano na podstawie: Dz.U. z 2013 r. poz. 330, 630, z 2014 r. poz. 768,1100 , z 2015 r. poz. 4,978, 1045, 1166, 1333. Kancelaria Sejmu 4.11.2015.

Zarządzanie wiedza w przedsiębiorstwie (2005), red. K. Perechuda, Wydawnictwo Naukowe PWN, Warszawa.

Zarządzanie zasobami ludzkimi (2006), Tworzenie kapitału ludzkiego organizacji, red. H. Król, A. Ludwiczyński, Wydawnictwo Naukowe PWN, Warszawa.

\section{SYSTEMATYKA KAPITALU INTELEKTUALNEGO (DYSKUSJA AKTUALNYCH KONCEPCJI)}

Streszczenie: Celem opracowania jest dokonanie ujęcia istoty ekonomicznej kapitału intelektualnego. Na podstawie źródeł literackich została wykonana analiza porównawcza definicji i klasyfikacji kapitału intelektualnego oraz przedstawiona jego kompleksowa charakterystyka. Biorąc pod uwagę ekonomiczną naturę każdego rodzaju kapitału, a także jego specyficzne cechy związane z czynnikiem osobowym i aspektem wiedzy, zaproponowano nową definicję kapitału intelektualnego w dwojakim, tj. węższym i szerszym, ujęciu, przedstawiono jego zasadniczą trzyelementową strukturę i opisano cele, dla osiągnięcia których niezbędne jest pogłębienie jego klasyfikacji. Przedstawiona systematyka powinna stanowić podstawę dla opracowywania metody oceny przedsięwzięć typu start-up dla Centrum Zarządzania Innowacjami i Transferem Technologii Politechniki Warszawskiej.

Słowa kluczowe: kapitał, kapitał intelektualny, kapitał ludzki, kapitał strukturalny, kapitał kliencki, definicja, klasyfikacja

\section{Citation}

Rykovska I. (2016), The Systematics of Intellectual Capital (a discussion of current concepts). Finanse, Rynki Finansowe, Ubezpieczenia, 1 (79), 299-311; www.wneiz.pl/frfu. 